\title{
Does Causal Relationships Exist between External Trade and Foreign Direct Investment Flow to Agriculture in Ghana?
}

\author{
Justice G. Djokoto \\ Department of Agribusiness, Central Business School \\ Central University College \\ P. O Box DS 2310, Dansoman, Accra, Ghana
}

Tel: 233-28-503-7399Ｅ-mail: dgameli2002@gmail.com

Received: August 5, 2011

doi:10.5539/ijbm.v7n2p179
Accepted: September 19, $2011 \quad$ Published: January 16, 2012

URL: http://dx.doi.org/10.5539/ijbm.v7n2p179

\begin{abstract}
The paper investigated the short-run and long-run relationship between external merchandise Agricultural trade and Foreign Direct Investment (FDI) inflows into the Agricultural sector of Ghana. The study employed Granger's instantaneous causality to assess the short-run relationship and feedback model to investigate the long-run relationships. Following the existence of unit-roots for the variables as well as cointegration, the Toda-Yamamoto procedure was followed for the estimation of the Vector Autoregressive (VAR) models. In the short-run, the coefficient for FDI inflows and imports were statistically significant. The negative sign pointed to a substitution or replacing relationship between the two variables. The coefficients between exports and FDI though negative, were not statistically significant. In the long-run, there was a feedback between imports and FDI. Exports caused FDI but not the reverse. Notwithstanding the transitory substitution effect of imports and FDI, in the long-run, imports and FDI complemented each other. Trade and FDI promotion should be pursued together.
\end{abstract}

Keywords: Foreign Direct Investment, External trade, Granger causality, Instantaneous causality, Toda-Yamamoto test

\section{Introduction}

\subsection{Background}

For the 70 percent of the world's poor who live in rural areas, agriculture is the main source of income and employment (World Bank, 2011). In Ghana, food and agriculture industry plays a major role in the economy. From 1990 to 1999 , the sector contributed an average of $41.3 \%$ to gross domestic product and $12.2 \%$ of national tax revenue. In 1999 alone, it recorded total foreign exchange earnings of $\$ 2.1$ billion and employed 54.3\% of the workforce (GIPC, undated). These were possible with both local and relatively low Foreign Direct Investments (FDI).

Any investment scenario in which the investor owns at least $10 \%$ of the foreign enterprise is called a FDI (OECD, 1999). FDI also connotes an investment involving a long-term relationship and reflecting a lasting interest and control of a resident entity in one economy in an enterprise resident in another economy (Rotjanapan, 2005). This suggests that FDI comprises international capital flows in which a firm in one country creates or expand a subsidiary in another. According to Krugman and Obstfeld (2009), the most distinctive feature of FDI is that it encompasses transfer of resources and acquisition of control. Consequently, UNCTAD (2008) delineates components of FDI as equity capital, reinvested earnings, and other capital.

The motive for offering special incentives to attract FDI frequently derives from the expectation that foreign investment produces externalities in the form of technology transfers and spillovers (Dash \& Sharm, 2007, Abor et al, 2008). Some benefits allure to FDI hosts especially developing countries. First, these spillovers, Romer (1993) noted, can promote the transfer of technological and business knowledge to poorer countries with economy-wide effects. Second, the reallocation can improve living standards by mobilising global savings to finance investments in countries where the marginal productivity of investment is relatively high resulting in efficiency gains (Summers, 2000). Other benefits include augmenting domestic capital for exports, new products for exports, facilitating access to new and large foreign markets, providing training for the local workforce, and 
upgrading technical and management skills (Abor, et al, 2008).

The benefits to be derived from FDI are dependent on the quality of the FDI rather than the quantity (Enderwick, 2005), and the absorptive capacity (Alfaro et al. 2004, Durham, 2004). Glass (undated) distinguished horizontal FDI, which is, duplication of similar stages of production across countries from vertical FDI. The vertical FDI described firms locating different stages of the production process in different countries. The determinants of the absorptive capacity include, but not limited to; the initial level of development (Blomström, et al., 1992), trade policy (Balasubramanyam et al, 1996), existing human capital development (Borensztein, et al. 1998), general government policy (Edison et al., 2002), financial development (Durham, 2004; Alfaro et al., 2004), and legal-based variables (Edison et a1, 2002, Durham, 2004).

\subsection{Problem statement}

As noted earlier, FDI has been identified to promote exports of host countries by augmenting domestic capital for exports, helping to transfer technology and new products for exports, facilitating access to new and large foreign markets, providing training for the local workforce, and upgrading technical and management skills. China, the Republic of Korea and, most significantly, the Gulf Cooperation Council countries of West Asia, in the wake of the recent food crisis, and in response to food security concerns, have increased FDI to agriculture in other southern countries. These countries are also major importers of grains, with large populations relative to arable land (Woertz, 2009; World Bank, FAO and IFAD, 2009; Freeman, et al, 2008). Given the fundamental importance of agriculture to most developing countries, its chronic neglect by many countries is of utmost concern (UNCTAD, 2009). Inflow of FDI is associated with personnel from non-host country with their own taste and culture. To keep these, goods would be imported. The development and manufacture of products may require imported inputs. On the other hand, the products of the FDI firms may be exported. The effects of these external trade components on FDI inflows to Agriculture are largely unknown. It is apt therefore to investigate the question: does causal relationships exist between external trade and FDI flow into agriculture in Ghana? Specifically, what are the long-term and short-term relationship between FDI and external trade of agricultural merchandise?

\subsection{Objectives}

The study seeks to investigate the relationship between FDI to agriculture and external trade of agricultural merchandise products in Ghana. Specifically, it seeks to assess the short-run and long-run relationship between trade and FDI flow to agriculture in Ghana.

\subsection{Relevance}

Krugell, (2005), Asiedu (2006) and Moreira (2009) have acknowledged a dearth of recent literature on causes of FDI flow into Africa. Some more recent cross-country studies on Africa have been conducted by Abdulai (2007), Mutenyo et al (2010), Blancheton and Opara-Opimba (2010) and Luiz \& Ruplal (2010) among several studies. The sparse country-specific studies on causes of FDI in Ghana notably, Tsikata et al (2000), Kyereboah-Cleman and Agyire-Tettey (2008) and Barthel et al, (2008) failed to examine sectoral dimensions. The couple of sectoral country studies by Amos (2003) on mining, Abdulai (2005) on sectoral (as defined by GIPC) FDI, and Dah \& Khadijah (2010) on Oil did not focus on manufacturing and/or agricultural sector, preferred for efficiency effects (Barthel et al, 2008). Indeed, single policy variable studies on external trade and inflow of FDI to agriculture are largely unknown. Additionally, the importance of agriculture to a developing country such as Ghana cannot be over stressed.

\subsection{Organisation of study}

The rest of the paper is organised into four sections. The next section presents the review of literature. The data sources and analyses procedure are presented in section 3. The results of the analyses and accompanying discussions are presented next. The paper concludes with recommendations in section 5 .

\section{Literature Review}

Theoretically, trade and FDI are centrepiece to the current paper. Whilst trade theories seek to explain why countries exchange goods among each other, FDI theory adopts three underpinning perspectives. Firstly, why a firm will favour FDI as a means of entering a foreign market other than exporting and licensing; secondly, why firms in the same industry often undertake FDI at the same time, and thirdly, why certain locations are favoured over others as a target for FDI.

The first perspective, which is internationalisation theory, seeks to explain why firms often prefer FDI to licensing as a strategy for entering a foreign market (Hymer, 1976). According to this theory, FDI is preferred to licensing and exporting owing to some drawbacks. In the case of licensing, it may result in a firm giving away valuable technological expertise to a potential foreign investor. Secondly, licensing does not give a firm the level 
of control over manufacturing, marketing, and strategy in a foreign country that may be required to maximise its profitability. The fee received for licensing is not commensurate with the loss of control over manufacturing and marketing. Thirdly, there is competitive advantage, where a firm's product is not a major driver of its competitive advantage, rather management, marketing, and manufacturing capabilities that produce those products. Such capabilities are often not amenable to licensing.

The second perspective explains the patterns of FDI. Firms invest in other countries as a following strategy. Firms follow their domestic competitors oversees. Knickerbocker (1973) first put forward this theory, which is based on Oligopolistic industries. A critical competitive feature of such industries is interdependence of the major players. These firms tend to imitate each other's FDI strategy. Closely linked to the follower strategy in explaining pattern of FDI is the product life cycle hypotheses by Vernon (1966). Accordingly, firms undertake FDI at particular stages in the life cycle of the product they pioneered. They invest in other advanced countries when local demand in those countries grows large enough to support local production. Production is subsequently shifted to developing countries when product standardisation and market saturation give rise to price competition and cost pressures. Investment in developing countries is seen as the best way to reduce cost.

Dunning's Eclectic paradigm is the third perspective, and it is popular in the discipline of international economics, and deducible from Dunning et al (1977) and Dunning (1988) theories about FDI. The theory posits that the extent, geography, and industrial composition of foreign production undertaken by Multinational Enterprise (MNE) is determined by the interaction of three sets of interdependent variables which, themselves, comprise the components of three sub-units (Dunnings, 2001). The mathematical function is:

$$
F D I=f(O, L, I)
$$

Where; $\mathrm{O}$ is ownership, $\mathrm{L}$ is location and $\mathrm{I}$ is internalisation.

Ownership, location, and internationalisation are key competitive advantages in this paradigm. The ownership competitive advantage posits that, ceteris paribus, the greater the competitive advantages of the investing firms, relative to those of other firms the more they are likely to be able to engage in, or increase, their foreign production (Dunning, 2001). The locational attractions, aver that the more the immobile, natural or created endowments, needed by the firms to use jointly with their own competitive advantages, favour a presence in a foreign, rather than a domestic location, the more firms will choose to supplement or take advantage of their ownership specific advantages by engaging in FDI. For this reason, the MNEs would undertake activities so as to add value to their operations.

The final competitive advantage which is internalisation, offers a framework for evaluating alternative ways in which firms may organise the creation and exploitation of their core competencies, given the locational attractions of different countries or regions. Such modalities range from buying and selling goods and services in the open market, through a variety of inter-firm non-equity agreements, to the integration of intermediate product markets and an outright purchase of a foreign company. In sum, the eclectic paradigm, like its near relative, internalisation theory, asserts that the greater the net benefits of internalising cross-border intermediate product markets, the more likely a firm will prefer to engage in foreign production itself, rather than license the right to do so, for example by a technical service or franchise agreement, to a foreign firm (Dunning, 1993).

Vernon (1966) proposed a linkage between trade (export and import) and FDI within the framework of the product life cycle. Earlier, Mundell (1957) in a neoclassical approach to trade theory put forward a relationship between trade in commodities and international capital flows. This certainly sets the stage for the link between FDI and international trade. In Mendell's view, tariff protection would create a perfect substitution between international capital flows and trade in commodities. This would be the case for perfect competition, and constant economies of scale within the Herscher-Ohlin-Samuelson (HOS) framework. More specifically, the effort of countries in building protectionism for their domestic and infant firms would lead to raising barriers to either trade or productive factor movements (Keuh, et al 2007). Increases in trade barriers would create opportunity for factor movements. Increases in the latter would then engender trade. This one-way and two-way prognosis implies substitutability or complementarity between trade and FDI.

Whilst empirical evidence on the relationship between agriculture FDI and agricultural trade is scarce, for the total economy level, evidence of such relationship abound. Kueh et al (2007) showed that import tends to substitute FDI in short run for ASEAN-5 nations. Mitze et al (2009) examining cross-variable linkages found substitutive links between trade flows and outward FDI in line with earlier empirical evidence for Germany. Decomposing the data into West and East Germany, and using EU27 trade and FDI as an example, they identified that pairwise linkages closely follow the theoretical predictions of New Trade Theory models as in Baldwin \& Ottaviano (2001); that is, when trade is merely of intra-industry type with non-zero trade costs, export replacement effects of FDI were observed. Mitze et al (2009) however, showed that at the same time, 
outward FDI stimulated trade via reverse good imports. Brainard (1993) in his study, introduced transportation costs and economies of scale at the plant level into his model. It was found that the substitutional relationship of exports and FDI depended on the trade-off between the proximity advantages (e.g. reduction of transaction costs) and scale advantages from concentrating production in a single location. Concerning trade costs as a proxy for transaction costs in an international context, it was clear that horizontal FDI is enforced if trade costs increase (Adenäuer and Henckelei, 2008). Additionally, they noted a substitutional (negative) relationship appeared mainly when horizontal (market seeking) FDI was undertaken, i.e. to serve customers in the foreign market.

In respect of complementarity, Marchant et al (2002) found a complementary relationship between FDI and exports for US food manufacturing. For ASEAN-5 nations, FDI and import complemented each other in the long run (Kueh et al, 2007). For the West German-EU15 sub-sample, Mitze et al (2009) observed that complementarities among export and outward FDI activity existed. Tadesse \& Ryan (2002) using the counts and values of Japanese aggregate FDI and trade flows into more than 100 geographically and developmentally diverse countries, showed that Japanese FDI in the 1990s was generally trade creating. However, the extent to which FDI complemented trade varied by geographic, developmental, and market servicing status of the host countries. They indicated that higher factor costs and exchange rate volatility lowered the occurrence and value of Japanese FDI. Additionally, Japanese FDI during the reference period was mostly tariff jumping. Abe (2002) and Lee (2002a), tested the effects of Japanese and Korean FDI on trade under the framework of a gravity equation. Japanese and Korean FDI tended to promote exports and overall trade. Lee (2002b) examined FDI-trade linkage between host and home countries, reflecting a special interest in the links between trade and FDI flows and their contribution to regional integration. Using patterns of procurement and sales of foreign affiliates of Japanese and Korean firms, he found a strong, positive relationship between Japanese (Korean) FDI into China and trade with China. Japan's (Korea's) FDI in China tended to stimulate Japan's (Korea's) exports significantly, and this positive effect appeared consistently. Head \& Ries, (2004) and Eurostat (2005) also documented a complementary (positive) relationship between FDI and trade flows as competition in the host country did not increase. This arose from the location of parts of the production chain in foreign countries (efficiency seeking; vertical FDI) to reduce production costs but served the home market (Adenäuer and Henckelei, 2008). Markusen (1983) provided empirical evidence for the hypothesis that FDI and exports have a complementary relationship. This followed from the elimination of barriers to factor movements between countries in the absence of protection of goods. Additionally, exports and FDI appeared in a complementary way if differences in production technology, product market distortion (production taxes, monopoly, increasing returns to scale) or factor market distortion existed (Adenäuer and Henckelei, 2008).

FDI and trade possess directional implications. Ghosh (2007), have shown that the source of this correlation is causality from FDI to trade openness, rather than the other way round in India. Additionally, a unidirectional causality, which runs from FDI to export as well as from FDI to import for India exists (Darsh \& Sharma, 2007). The empirical analysis of Harding \& Javorcik (2011) related unit values of exports measured at the 4-digit SITC level to data on sectors treated by investment promotion agencies as priority in their efforts to attract FDI. The sample covered 105 countries over the period 1984-2000. The findings were consistent with positive effect of FDI on unit values of exports in developing countries. In the decade of the 1990s, V. N. Balasubramanyam and collaborators published a number of papers, with compelling arguments and supporting evidence, that export-promoting trade and investment strategies attract more and more productive inflows of foreign capital than do import-substituting strategies (Greenway et al 2007). In the new millennium, Greenway et al, (2007) found these evidences robust.

At the firm level, there exists a positive relationship between FDI and export performance (Abor, et al, 2008). They noted the relevance of FDI in influencing the export decisions and export performance of Ghanaian firms.

\section{Methods}

\subsection{Model}

A number of papers on FDI developed theoretical models for analyses. Specifically, Barrell \& Pain (1996) developed a theoretical model that focused solely on FDI using profit maximisation theory, while Bajo-Rubio and Sosvilla-Rivero (1994) used cost minimization theory for their FDI model. Gopinath et al (1999) developed a theoretical model for FDI using profit maximisation theory. However, this paper concerns itself with concept of causality employed Granger (1969) framework for analyses. This study revisits the seminal work of Granger (1969) (using the exact words, phrases, and notations in some instances). If $A_{t}$ is a stationary stochastic process, let $\bar{A}_{t}$ represent the set of past values $\left\{A_{t-j}, j=1,2, \ldots, \infty\right\}$ and $\overline{A_{t}}$ represent the past and present values $\left\{A_{t-j}\right.$, $j=0,1, \ldots, \infty\}$. Additionally, let $\bar{A}(k)$ represent the set $\left\{A_{t-j}, j=k, k+1, \ldots, \infty\right\}$. Then, the optimum, unbiased, least-squares predictor $A_{t}$ using the set of values of $B_{t}$ is shown as $P_{t}(A \mid B)$. Furthermore, the associated predictive 
error process would be denoted as $\varepsilon_{t}(A \mid B)=A_{t}-P_{t}(A \mid B)$. Thus, the variance of this error process is represented as $\sigma^{2}(A \mid B)$.

Based on the preceding assumptions in set notation, Granger (1969) provided four dimensions of causality, namely; causality (unidirectional), feedback (bidirectional), instantaneous and causality lag. The study employed the first two dimensions. However, the second, feedback or bidirectional is presented as it encompasses the unidirectional as well.

If $\sigma^{2}(X \mid U)<\sigma^{2}(X \mid \overline{U-Y})$, then $Y$ causes $X$, denoted by $Y_{t} \Rightarrow X_{t}$. Then, $Y_{t}$ is causing $X_{t}$ if it is better to predict $X_{t}$ using all available information than if the information apart from $Y_{t}$ had been used. Assuming a stationary time series with zero means of $X_{t}$ and $Y_{t}$ so that:

$$
\begin{gathered}
X_{t}=\sum_{j=1}^{m} a_{j} X_{t-j}+\sum_{j=1}^{m} b_{j} Y_{t-j}+\varepsilon_{t} \\
\underset{t}{Y=\sum_{j=1}^{m} c_{j} X_{t-j}}+\sum_{j=1}^{m} d Y_{j-j}+\eta_{t}
\end{gathered}
$$

where $\varepsilon_{t}$ and $\eta_{t}$ are taken to be two uncorrelated white-noise series, so that $E\left[\varepsilon_{t} \varepsilon_{s}\right]=0=E\left[\eta_{t} \eta_{s}\right], s \neq t$, and $E\left[\varepsilon_{t} \varepsilon_{s}\right]=0$ for all $t, s$. From 2 and $3, m$ is less than the time series for the estimation. From 2, $Y_{t}$ causes $X_{\mathrm{t}}$ if more than one $b_{j}$ is not statistically different from zero. On the other hand, $X_{t}$ causes $Y_{\mathrm{t}}$ if any of the $c_{j}$ is not statistically equal to zero in equation 3. Granger (1969) described either of the above cases as causality, more appropriately as unidirectional or one-way causality. Both cases he christened 'feedback' stated differently, as bidirectional causality. A third definition of causality, instantaneous causality was described as follows (based on Granger's symbols and notations):

$$
\begin{gathered}
X_{t}=\sum_{j=1}^{m} a_{j} X_{t-j}+\sum_{j=1}^{m} b_{j t-j}+b_{t} Y+\varepsilon_{t} \\
Y_{t}=\sum_{j=1}^{m} c X_{t-j}+\sum_{j=1}^{m} d Y+j t-j+{ }_{0} X+\eta_{t}
\end{gathered}
$$

So that, if $b_{0}$ is statistically different from zero, then Yt instantaneously causes $X_{t}$. The reverse is true, if, $c_{0}$ is statistically different from zero. Substituting the variables of the study, the following equations were obtained:

$$
\begin{gathered}
A G F D I=\sum_{j=1}^{m} \alpha_{j} A G F D I_{t}+\sum_{j=1}^{m} \beta_{j} A G I M P_{t}+\varepsilon_{t} \\
A G F D I=\sum_{j=1}^{m} \chi_{j} A G F D I_{t}+\sum_{j=1}^{m} \delta_{j} A G E X P_{t}+\gamma_{t} \\
A G E X P_{t}=\sum_{j=1}^{m} \phi_{j} A G E X P_{t}+\sum_{j=1}^{m} \varphi_{j} A G F D I_{t}+\lambda_{t} \\
A G I M P=\sum_{t}^{m} \imath_{j} A G I M P_{t}+\sum_{j=1}^{m} \kappa_{j} A G F D I_{t}+\omega_{t} .
\end{gathered}
$$

Where $\alpha_{j} \quad \beta_{j} \quad \chi_{j} \delta_{j} \quad \phi_{j} \quad \varphi_{j} \quad \iota_{j} \quad \kappa_{j}$ are coefficients. 
Granger (1969) assumed that the time series data employed in the tests must be stationary. However, as is often the case, time series data are often not stationary. Toda \& Yamamoto (1995) improved upon the traditional Granger causality test by introducing the order of integration of the variables. Thus, the maximum lag $m$, in the view of Toda \& Yamamoto (1995) (T-Y test) is the optimal lag as required by Granger plus the maximal order of integration. So for example, if a series is differenced once to obtained stationarity, then, the $d_{\max }$ is 1 . Thus, $m=k+d_{\text {max }}$.

\subsection{Data Sources and Descriptions}

Agricultural inward FDI (AGFDI) captured as estimated project cost was obtained from Ghana Investment Promotion Centre (GIPC) in US dollars. However, the data covered 1995 to 2010. To generate data for 1966-1994, a model with AGFDI as dependent and Net FDI (obtained from UNCTADSTAT database) as independent variable was estimated. The model was used to estimate data for 1971-1995. An exponential growth equation was then applied to the 1971 to 2010 data to fill in the spaces for 1961-1970. Data on agricultural exports and imports in current US dollars was obtained from FAOSTAT database. The series covered 1961 to 2008. Data used in the analyses covered 1961 to 2008.

\section{Results and Discussion}

\subsection{Descriptive statistics}

Over the 48 years period, the maximum annual value of exports was US\$1.5bn (2008), with a minimum of US $\$ 0.19 \mathrm{bn}(1961)$ as shown in Table 3 . The mean of US $\$ 0.52 \mathrm{bn}$ is only US $\$ 0.12 \mathrm{bn}$ away from the median export value. The mean import value of US\$0.235bn is less than half the mean value of exports, the difference registering a value of US $\$ 0.285$. This commendable positive net visible trade in agriculture may be attributable to the importance of agriculture in Ghana's economy.

\subsection{Correlation Output}

To get a glimpse of the relation among the variables under study, bivariate correlation was estimated (Table 4).

All pairwise coefficients are significant at $1 \%$ level; in fact, the exact probability levels were all 0.00 . This is suggestive of a strong relation between FDI and exports as well as imports in Ghana's agriculture. Since correlations do not necessarily establish causation, such cannot be adduced at this stage.

\subsection{Unit-root and cointegration Tests}

As was noted in section 3.1, the causality test is only valid if the series is stationary. Hence, the variables were tested for the existence of unit roots. The results in Table 1 show that all the variables were non-stationary at levels. The results of ADF and PP were largely consistent and for all model types. The exception is AGIMP for the most restricted model and unrestricted model. For both models, unlike PP, the series of AGIMP attained stationarity with ADF after the second differencing. In the T-Y test, the maximum order of integration is employed. Thus, the conclusion was I (2). Having obtained the maximal order of integration, the next requirement was to generate $k$, the optimal length. The usual methods were Log likelihood (LL), Akaike information criteria (AIC) and Shwarz criteria (SC) with results in Table 6. Using AIC the optimal lag for AGFDI and AGEXP pair is 1, whilst that of AGFDI, AGIMP pair is 2.

\subsection{Long-run Analyses}

The following equations were then estimated using Eviews 7:

$$
\begin{array}{r}
A G F D I=\sum_{j=1}^{2} \alpha_{j} A G F D I_{t}+\sum_{j=1}^{4} \beta_{j} A G I M P_{t}+\varepsilon_{t} \\
A G F D I=\sum_{j=1}^{3} \chi_{j} A G F D I_{t}+\sum_{j=1}^{3} \delta_{j} A G E X P_{t}+\gamma_{t} \\
A G E X P=\sum_{j=1}^{3} \phi_{j} A G E X P_{t}+\sum_{j=1}^{3} \varphi_{j} A G F D I_{t}+\lambda_{t} . \\
A G I M P=\sum_{j=1}^{4}{ }_{t} A G I M P+\sum_{j}^{2} \kappa_{j} A G F D I+\omega_{t}
\end{array}
$$




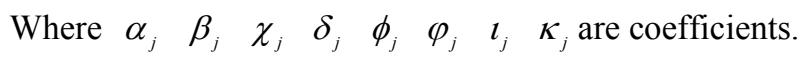

The results in Table 7, show that the null hypothesis, that, 'AGIMP does not Granger cause AGFDI' was rejected in favour of the alternative hypothesis, that, 'AGIMP does Granger cause AGFDI'. The practice of importing into a country and later follow up to set up production facilities may be attributable to this outcome. The results conform to the findings of a long-run relationship between FDI and imports (Mitze et al, 2009). The positive sign of the coefficients also connote complementarity of FDI and external trade, which is consistent with the conclusions of Kueh et al (2007).

In respect of exports Granger Causing FDI, the null hypothesis could not be upheld. The level of probability recorded was 0.00 . Hence, the alternative hypothesis that 'AGEXP does Granger cause AGFDI' holds. These findings of complementarity of FDI and trade flows agrees with the earlier study of Tadesse \& Ryan (2002) as well as those of Abe (2002) and Lee (2002a). Cocoa beans constitute the greatest single crop contributing to Ghana's agricultural exports. The dominance of indigenous and non-plantation farms structure does not encourage foreign investment in production of cocoa beans. Additionally, the price of cocoa beans is regulated, which constitute some disincentive to foreign investors who may not reap the full foreign prices of the beans sold. Thus, increased agricultural exports over the period 1961 to 2008 have failed to signal and cause an inward flow of FDI into the sector. The likelihood of exports Granger causing agro-processing FDI may be possible as foreign firms may wish to locate in Ghana to take advantage of labour and get closer to the primary product.

The null hypothesis that 'AGFDI does not Granger cause AGIMP' is also rejected in favour of the alternative hypothesis that 'AGFDI does Granger cause AGIMP'. The findings conform to the conclusions of Abe (2002) and Lee (2002a). A recent study by Harding \& Javorcik (2011) confirms a positive relation between FDI and exports. Existing foreign firms and new entrants will need to import some capital items. Indeed, firms that have parent companies abroad may import raw materials from them. To a less extent, foreign employees would generally prefer goods from their home country and this may lead to increased imports.

The only exception to the rejection of the null hypothesis is the case of 'AGFDI does not Granger Cause AGEXP'. The null hypothesis could not be rejected. This result seems interesting. This is because one will expect foreign firms to generate more exports. However, as the results suggest, in as much as there may be export-oriented FDI projects; the exports generated may still be far from adequate in inducing (more) FDI. This becomes clearer; as noted earlier, that, the bulk of Ghana's agricultural exports are made of cocoa beans, the production of which is largely an indigenous phenomenon and not an attraction to foreign firms. The above result confirms the finding of Harding \& Javorcik (2011) of a positive relation between export and FDI. Additionally, the results confirm the findings of Markusen (1983)., Head \& Ries, (2004) and Eurostat (2005).

\subsection{Short-run Analyses}

The results discussed thus far, relate to long-run relationship between external trade components and FDI inflows to agriculture. In order to investigate short-term relationships, Granger's instantaneous causality was used. The estimated equations are presented below.

$$
\begin{gathered}
A G F D I=a_{0}+a_{1} A G I M P_{t}+\sum_{j=1}^{4} \mu_{j} A G I M P_{t}+\sum_{j=1}^{2} v_{j} A G F D I_{t}+\varpi_{t} \\
A G F D I=b_{0}+b_{1} A G E X P_{t}+\sum_{j=1}^{3} o_{j} A G E X P_{t}+\sum_{j=1}^{3} \pi_{j} A G F D I_{t}+\vartheta_{t} \\
A G I M P_{t}=c_{0}+\sum_{j=1}^{4} \theta_{j} A G I M P_{t}+c_{1} A G F D I_{t}+\sum_{j=1}^{2} \sigma_{j} A G F D I_{t}+\varsigma_{t} \\
A G E X P_{t}=d_{0}+\sum_{j=1}^{3} \tau_{j} A G E X P_{t}+d_{1} A G F D I+\sum_{j=1}^{3} v_{j} A G F D I_{t}+\rho_{t}
\end{gathered}
$$

Where $\mathrm{a}_{0}, \mathrm{~b}_{0}, \mathrm{c}_{0}$, and $\mathrm{d}_{0}$ are constants, $a_{1}, b_{1}, c_{1}, d_{1}, \mu_{j}, v_{j} o_{j} \pi_{j} \theta_{j} \sigma_{j} \tau_{j}$ and $v_{j}$ are coefficients and ${ }_{t}{ }_{t}{ }^{\vartheta} t,{ }_{t}{ }_{t}$, and $\rho_{t}$ are respective error terms of equation $14,15,16$, and 17 . The number of lags is represented by $j$ s. 
The estimations of equations 14, 15, 16 and 17 are presented in Table 8 . For all equations, the $F$ statistic is significant at $1 \%$ level. Additionally, the adjusted $R^{2}$ exceeds $50 \%$. Furthermore, the $D . W$. statistics are all close to 2.0 , suggesting that there is no first-order autocorrelation. With these properties of the models, they are appropriate to be used for inferences. The empirical results of model 14 and 16 respectively show the statistical significance of the current value of AGIMP and AGFDI. Thus, the null hypothesis that the current value of AGIMP does not cause AGFDI is rejected in favour of the alternative hypothesis that the current value of AGIMP causes AGFDI.

In respect of equation 16, the current value of AGFDI causes imports. From the above there is a bidirectional instantaneous Granger causality between imports and FDI to agriculture in Ghana. However, for all four equations, there exists a negative relation between the dependent variable and the current value of the explanatory variables. These point to short-run substitution between FDI and external trade components. Specifically, an increase in FDI inflow to Agriculture leads to decrease in the current year value of agricultural imports. The converse holds true. This is consistent with the findings of Kueh, et al, (2007). As stated earlier, the substitutional relationship of exports and FDI depends on the trade-off between the proximity advantages (e.g. reduction of transaction costs) and scale advantages from concentrating production in a single location (Brainard, 1993). Thus far, the relation between trade and FDI fits I in Dunning's model, that is internationalisation theory.

\section{Conclusions and Recommendations}

There is an instantaneous causality between FDI inflows and agricultural merchandise imports. The negative coefficients confirm that imports of agricultural merchandise are FDI replacing and vice versa in the short-run. In the long-run however, the converse is found; FDI inflow to Agricultural sector in Ghana complements trade. Based on the data, there is feedback (to use the words of Granger (1969)) between FDI inflow into agriculture and imports. Whilst, exports cause FDI inflows, in the long-run, FDI does not lead to exports of agricultural merchandise in Ghana over the period 1961-2008. The link between FDI and trade confirm Vernom (1966) assertion of trade and FDI albeit not within the product life cycle context. The mixed evidence on vertical and horizontal FDI between the EU15 and the host countries leaves open if the overall relationship between FDI and trade is complementary (vertical) or substitutional (horizontal). It is likely that both types of flows exist with a different weight (Adenäuer and Henckelel, 2008). The transitory substitution of FDI by trade notwithstanding, more vigorous exports promotion is required as a means of attracting FDI into agriculture in Ghana in the long-run. Since exports of agricultural products does not Granger cause AGFDI, the likelihood of exports Granger causing agricultural processing FDI could be investigated.

A principal limitation of the study must be noted. In the period till 1983, (for about half of the study period) Ghana's economy has been essentially closed. Thus FDI during those times were largely unresponsive to trade. Indeed for the greater part of that time import substitution policy was in place. During the same period, the effect of macroeconomic variables that could influence trade positively may largely have been ineffective.

\section{References}

Abdulai, D.N. (2007). Attracting Foreign Direct Investment for Growth and Development in Sub-Saharan Africa: Policy Options and Strategic Alternatives. Africa Development, XXXII (2), 1-23.

Abdulai, I. (2005). Sectoral Analysis of Foreign Direct Investment in Ghana, Working Paper WP/BOG-05/15, Bank of Ghana. Accra. Ghana. [Online] Available: http://www.bog.gov.gh/privatecontent/File/Research/Working\%20Papers/WP-15.pdf (2 ${ }^{\text {nd }}$ March, 2011)

Abe, K. (2002). Direct Investment in Northeast Asia: Perspectives and Issues. Mimeograph.

Abor, J., Adjasi, C. K. D., and Hayford, M. (2008). How Does Foreign Direct Investment Affect the Export Decisions of Firms in Ghana? African Development Review, 20 (3), 446-465. http://dx.doi.org/10.1111/j.1467-8268.2008.00193.x

Adenäuer, L and Henckelel, T. (2008). Determinants of European FDI into the Mediterranean and Mercosur Agribusiness sector. Selected Paper at the XIIth Congress of the EAAE "People, Food and Environments: Global Trend and European Strategies" in Gent, 26 - 29 August 2008.

Alfaro L., Chanda, A., Kalemli-Ozcan, S., and Sayek, S. (2004). FDI and Economic Growth: The Role of Local Financial Markets. Journal of International Economics, 64 (1), 89-112. http://dx.doi.org/10.1016/S0022-1996(03)00081-3

Amos, G.J. (2003). Unlocking the Wealth of Nations: FDI to the Rescue? A Case Study of the Gold Mining Industry of Ghana, International Business Master Thesis No 2003: 62, Graduate Business School, School of Economics and Commercial Law, Göteborg University. ISSN 1403-851X, Printed by Elanders Novum. [Online] Available: http://gupea.ub.gu.se/bitstream/2077/2284/1/inlaga_2003_62.pdf. 
Asiedu, E. (2006). Foreign Direct Investment in Africa: The Role of Natural Resources, Market Size, Government Policy, Institutions and Political Stability. World Economy, 29 (1), 63-77.

Bajo-Rubio, O., and Sosvilla-Rivero, S. (1994). An Econometric Analysis of Foreign Direct Investment in Spain. Southern Economic Journal, 6, 104-20. http://dx.doi.org/10.2307/1060133

Balasubramanyam, V.N., Salisu, M., and Sapsford, D. (1996). Foreign Direct Investment and Growth in EP and IS Countries. The Economic Journal, 106 (434), 92-105. http://dx.doi.org/10.2307/2234933

Baldwin, R., and Ottaviano, G. (2001). Multiproduct Multinationals and Reciprocal FDI Dumping. Journal of International Economics, 55, 429-448. http://dx.doi.org/10.1016/S0022-1996(00)00099-4

Barrell, R., and Pain, N. (1996). An Econometric Analysis of U.S. Foreign Direct Investment. Review of Economics and Statistics, 78, 200-207. http://dx.doi.org/10.2307/2109921

Barthel, F., Busse, M., and Osei, R. (2008). The Characteristics and Determinants of FDI in Ghana. Hamburg Institute of International Economics (HWWI), Germany. [Online] Available: http://www.hwwi.org/fileadmin/hwwi/Publikationen/Research/Paper/Weltwirtschaft/HWWI_Research_Paper_215.pdf (2nd March, 2011)

Blancheton, B, and Opara-Opimba, L. (2010). Foreign Direct Investment in Africa: What are the Key Factors of Attraction aside from Natural Resources? Working Papers of GREThA, n2010-14. [Online] Available: http://ideas.repec.org/p/grt/wpegrt/2010-14.html ( $2^{\text {nd }}$ March, 2011)

Blomström, M., Lipsey, R. E., and Zejan, M. (1992). What Explains Developing Country Growth? NBER Working Paper Series, No.4132.

Borensztein, E., De Gregorio, J., and Lee, J-W. (1998). How Does Foreign Direct Investment affect Economic Growth? Journal of International Economic, 45 (1), 115-135. http://dx.doi.org/10.1016/S0022-1996(97)00033-0

Brainard, S. (1993). A Simple Theory of Multinational Corporations and Trade with a Trade-off between Proximity and Concentration. Cambridge: NBER Working Paper, no. 4269.

Dah, F.K., \& Khadijah M.S. (2010). The Contribution of Oil to the Economic Development of Ghana: the Role of Foreign Direct Investments (FDI) and Government Policies, Master thesis in International Business 15 ECT, Department of Economics and Informatics, University West, Spring term 2010. [Online] Available: http://hv.diva-portal.org/smash/get/diva2:331510/FULLTEXT01 ( $2^{\text {nd }}$ March, 2011)

Darsh R. K., \& Sharma, C. (2007). FDI, Trade, and Growth in India: A Modified Causality Analyses. Journal of Indian School of Political Economy, 9 (3), 451-467.

Dunning, J. H. (1988). The Eclectic Paradigm of International Production: A Restatement and Some Possible Extensions. Journal of International Business Studies, 19 (1), 1-31. http://dx.doi.org/10.1057/palgrave.jibs.8490372

Dunning, J. H. (1993). Multinational enterprises and the global economy. Addison-Wesley Publishers, London.

Dunning, J. H. (2001). The Eclectic (OLI) Paradigm of International Production: Past, Present and Future. Journal of the Economics of Business, 8 (2), 173-190. http://dx.doi.org/10.1080/13571510110051441

Dunning, J.H., et al. (1977). Trade, Location of Economic Activity and MNE: a search for an Eclectic Approach. In: Ohlin, B. (Ed.). The international allocation of economic activity, (pp. 395-418). Macmillan, London.

Durham, J. B. (2004). Absorptive Capacity and the Effects of Foreign Direct Investment and Equity Foreign Portfolio Investment on Economic Growth. European Economic Review, 48 (2), 285-306. http://dx.doi.org/10.1016/S0014-2921(02)00264-7

Edison H. J., Levine R., Ricci L., and Slok, T. (2002). International Financial Integration and Economic Growth. Journal of International Money and Finance, 21, 749-776. http://dx.doi.org/10.1016/S0261-5606(02)00021-9

Enderwick, P. (2005). Attracting "Desirable" FDI: Theory and Evidence. Transnational Corporations, 14 (5), 93-119.

Engle, R.F., and Granger, C.W.J. (1987). Cointegration and Error Correction: Representation Estimation and Testing. Econometrica, 55 (2), 251-276.

Eurostat (2005). European Union Foreign Direct Investment Yearbook 2005. Theme, Luxembourg.

Freeman, D. Holslag, J., and Wei, S. (2008). China's Foreign Farming Policy: Can Land Provide Security? Asia Paper, Brussels: BICCS. [Online] Available: www.vub.ac.be/biccs/

Ghosh, I. (2007). The Relation between Trade and FDI in Developing Countries-A Panel Data Approach. Global Economy Journal, 7 (3), 1-30. http://dx.doi.org/10.2202/1524-5861.1272 
GIPC (undated). Ghana Investment Profile: Food Production and Processing. [Online] Available: http://www.gipc.org.gh/UserFiles/File/sector_profiles/Food.pdf (31 ${ }^{\text {st } J u l y, ~ 2011) ~}$

Glass, A. (undated). World Economy Vertical versus Horizontal FDI. [Online] Available: http://econweb.tamu.edu /aglass/VerticalVsHorizontalFDI.pdf (24 $4^{\text {th }}$ June2011)

Gopinath, M., Pick, D., and Vasavada, U. (1998). Exchange Rate Effects on the Relationship between FDI and Trade in the U.S. Food Processing Industry. American Journal of Agricultural Economics, 80 (5), 1073-1079. http://dx.doi.org/10.2307/1244207

Granger, C.W.J. (1969). Investigating Causal Relations by Econometric Models and Cross-spectral Methods. Econometrica, 37 (3), 424-438. [Online] Available: http://www.jstor.org/stable/1912791

Greenaway, D., Sapsford, D., and Pfaffenzeller, S. (2007). Foreign Direct Investment, Economic Performance and Trade Liberalisation. The World Economy, 30, 197-210. http://dx.doi.org/10.1111/j.1467-9701.2007.00887.x

Harding, T and Javorcik, B. S. (2011). FDI and Export Upgrading. Discussion Paper Series. No. 256. Department of Economics, University of Oxford, Manor Road Building, Oxford OX1 3UQ

Head, K., and Ries, J. (2004). Exporting and FDI as Alternative Strategies. Oxford Review of Economic Policy, 20 (3), 409-423. http://dx.doi.org/10.1093/oxrep/grh024

Hymer, S. H. (1976). The International Operation of National Firms: A Study of Direct Foreign Investment. Cambridge, MA: MIT Press.

Knickerbocker, F. (1973). Oligopolistic Reaction and Multinational Enterprise. Cambridge, MA: Harvard University Press.

Krugell, W. (2005). The determinants of foreign direct investment in Africa, in: Gilroy, B., Gries, T. and Naude, W. (eds). Multinational enterprises, foreign direct investment and growth in Africa: south-African perspectives, Physica-Verlag GmbH \& Co, Berlin.

Krugman, P., and Obstfeld, M. (2009). International economics theory \& policy. (8th Ed.). Pearson Addison Wesley, USA.

Kueh, J., Swee-Hui, P., Chin-Hong, L., \& Evan Shazali, A. M. (2007). FDI-trade Nexus: Empirical Analysis on ASEAN-5. MPRA Munich Personal RePEc Archive. Paper No. 522. [Online] Available: http://mpra.ub.uni-muenchen.de $/ 5220 /\left(19^{\text {th }}\right.$ April, 2011)

Kyereboah-Cleman, A, and Agyire-Tettey, K.F. (2008). Effect of Exchange-Rate Volatility on Foreign Direct Investment in Sub-Saharan Africa: The Case of Ghana. The Journal of Risk Finance, 9 (1), 52-70. [Online] Available: http://www.emeraldinsight.com/1526-5943.htm ( $2^{\text {nd }}$ March, 2011)

Lee, Chang-Soo (2002a). Korea's FDI Outflows: Choice of Locations and Effect on Trade. KIEP Working paper 02-07, KIEP.

Lee, Chang-Soo. (2002b). The Linkage between the FDI and Trade of China, Japan and Korea: The Korean Perspective. Seoul: Korean Institute for International Economic Policy. Paper prepared for presentation at the DRC/NIRA/KIEP symposium on Strengthening Economic Cooperation in Northeast Asia: Facilitating Investment between China, Japan and Korea held in Beijing on September 29, 2002. [Online] Available: http://unpan1.un.org/intradoc/groups/public/documents/APCITY/UNPAN014176.pdf (19 ${ }^{\text {th }}$ April, 2011)

Luiz, J., and Ruplal, M. (2010). Foreign Direct Investment and the Internationalisation of South African Mining Companies into Africa. Working Paper No. 194 Wits Business School, University of the Witwatersrand [Online] Available: http://www.econrsa.org/wp194.html (2 $2^{\text {nd }}$ March, 2011)

Marchant, M. A., Cornell, D. N., \& Koo, W. (2002). International Trade and Foreign Direct Investment: Substitutes or Complements? Journal of Agricultural and Applied Economics, 34 (2), 289-302

Markusen, J. (1983). Factor Movements and Commodity Trade as Complements. Journal of International Economics, 14, 341-356. http://dx.doi.org/10.1016/0022-1996(83)90009-0

Mitze, T. Alecke, B., and Untiedt, G. (2009). Trade-FDI Linkages in a System of Gravity Equations for German Regional Data. Ruhr Economic Papers \#84. [Online] Available: http://papers. ssrn.com/sol3/papers.cfm?abstract_id=1373791 (19 ${ }^{\text {th }}$ April, 2011)

Moreira, S.B. (2009). The Determinants of Foreign Direct Investment: What is the Evidence for Africa? UNISUL, Tuarão, 2 (1), 63-84.

Mundell, R. A. (1957). International Trade and Factor Mobility. American Economic Review, 47(3), 321-335. 
Mutenyo, J., Asmah, E., and Kalio, A. (2010). Does Foreign Direct Investment Crowd-out Domestic Private Investment in Sub-Saharan Africa? The African Finance Journal, 12 (1), 27-51.

OECD (1999). OECD benchmark definition of foreign direct investment. (3rd Ed.). Paris.

Romer, P. M. (1993). Idea Gaps and Objects Gaps in Economic Development. Journal of Monetary Economy, $32(3), 543-573$.

Rotjanapan, A. (2005) Topics in Foreign Direct Investment. The University of Kansas. Doctoral Dissertation submitted to the Department of Economics, University of Kansa, USA.

Summers, L. H. (2000). International Financial Crises: Causes, Prevention and Cures. American Economic Review Papers and Proceedings, 90 (2), 1-16. http://dx.doi.org/10.1257/aer.90.2.1

Tadesse, B., and Ryan M. (2002). The FDI-Trade Relationship: Are Developing Countries Different? Paper prepared for North eastern Universities Development Consortium Conference at Williams College, Williamstown, MA. [Online] Available: http://web.williams.edu/Economics/neudc/papers/ TadesseRyanNEUDC.pdf (19 ${ }^{\text {th }}$ April, 2011)

Toda, H.Y and Yamamoto, T. (1995). Statistical Inference in Vector Autoregressions with Possibly Integrated Processes. Journal of Econometrics, 66, 225-250. http://dx.doi.org/10.1016/0304-4076(94)01616-8

Tsikata, G.K., Y. Asante and E.M. Gyasi. (2000). Determinants of foreign direct investment in Ghana. Overseas Development Institute. London (UK).

UNCTAD. (2002). Foreign Direct Investment Statistics.

UNCTAD. (2009). World Investment Report. Transnational Corporations, Agricultural Production and Development. United Nations Conference on Trade and Development, United Nations, New York and Geneva.

Vernon, R. (1966). International Investment and International Trade in the Product Cycle. Quarterly Journal of Economics, 80 (2), 190-207. http://dx.doi.org/10.2307/1880689

Woertz, E. (2009). Outward Agricultural FDI by GCC countries. Paper prepared for UNCTAD, mimeo.

World Bank, FAO and IFAD. (2009). Improving Food Security in Arab Countries. Washington, DC: World Bank.

World Bank. (2011). [Online] Available: http://data.worldbank.org/topic/agriculture-and-rural-development ( $31^{\text {st }}$ July, 2011) 
Table 1. Lag Choice for VAR Model (AGFDI and AGIMP)

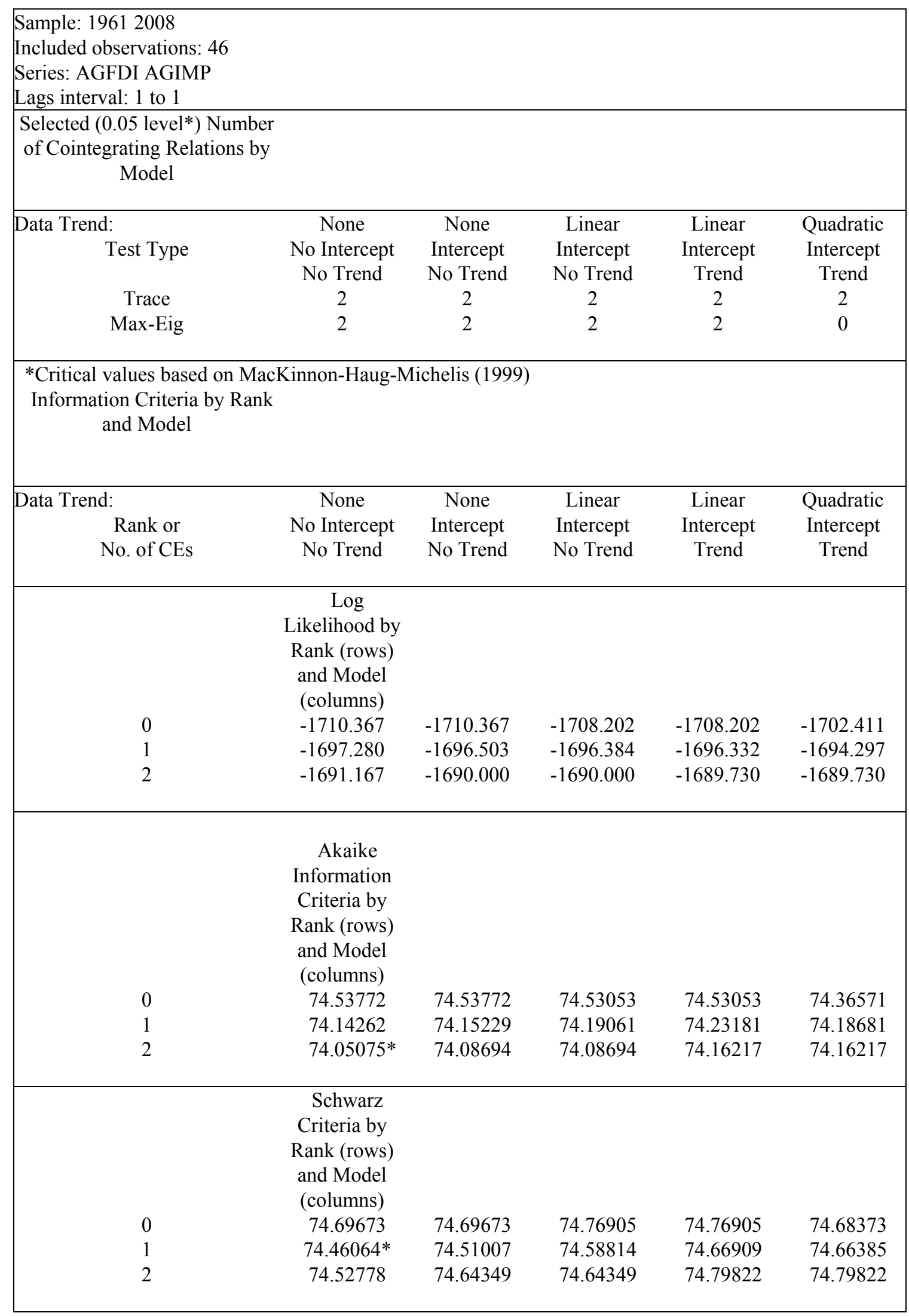


Table 2. Lag Choice for VAR Model (AGFDI and AGEXP)

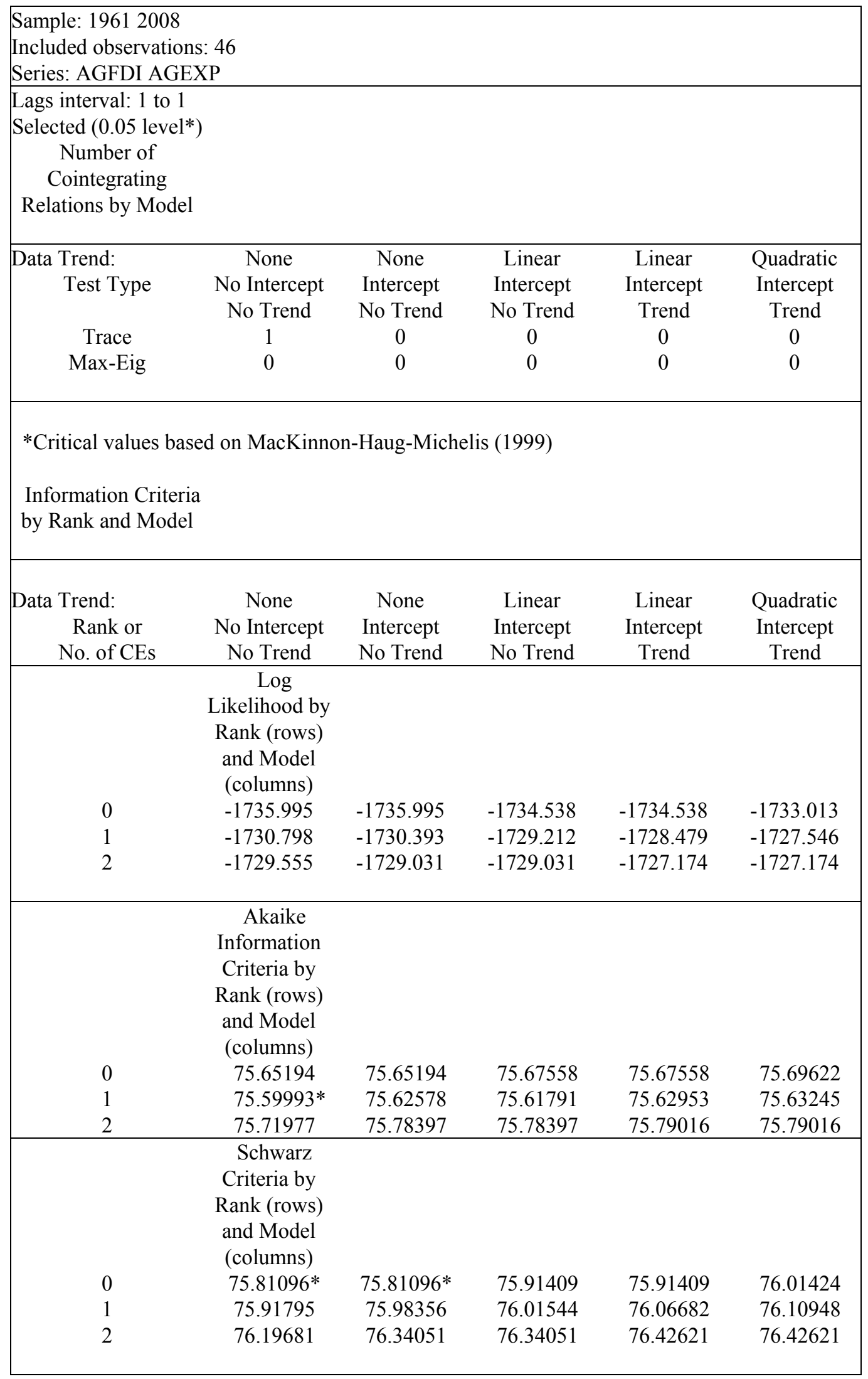


Table 3. Summary Statistics

\begin{tabular}{|l|c|c|c|}
\hline & AGFDI & AGIMP & AGEXP \\
\hline Mean & 8188212 & 235000000 & 520300000 \\
\hline Median & 3560089 & 100000000 & 400000000 \\
\hline Maximum & 55612844 & 1300000000 & 1500000000 \\
\hline Minimum & 127396.5 & 50000000 & 199000000 \\
\hline Std. Dev. & 13108654 & 291000000 & 343000000 \\
\hline Observations & 48 & 48 & 48 \\
\hline
\end{tabular}

Table 4. FDI, Trade Pearson Correlation Coefficients

\begin{tabular}{|l|r|r|r|}
\hline & \multicolumn{1}{|c|}{ Agric. FDI } & Agric. Imports & \multicolumn{1}{c|}{ Agric. Exports } \\
\hline Agric. FDI & 1 & $0.485(* * *)$ & $0.412(* * *)$ \\
Agric. Imports & $0.485(* * *)$ & 1 & $0.869(* * *)$ \\
Agric. Exports & $0.412(* * *)$ & $0.869(* * *)$ & 1 \\
& & & \\
\hline
\end{tabular}

*-significant at $10 \%$ level, $* *$-significant at $5 \%$ level, $* * *$-significant at $1 \%$

Table 5. Unit Root Tests

\begin{tabular}{|c|c|c|c|c|c|c|c|c|}
\hline \multirow{2}{*}{ Variables } & \multirow{2}{*}{ Model } & \multicolumn{3}{|c|}{ ADF } & \multicolumn{3}{|c|}{ PP } & \multirow{2}{*}{ Conclusion } \\
\hline & & Lag & \#Diff. & t-statistic & Band-width & \#Diff. & t-statistic & \\
\hline \multirow{3}{*}{ AGFDI } & None & 0 & 1 & -6.94 & 7 & 1 & -7.06 & I (1) \\
\hline & Constant & 0 & 1 & -6.95 & 8 & 1 & -7.26 & I (1) \\
\hline & $\begin{array}{l}\text { Constant } \\
\text { and Trend }\end{array}$ & 0 & 1 & -6.99 & 8 & 1 & -7.34 & I (1) \\
\hline \multirow{3}{*}{ AGIMP } & None & 2 & 2 & $-9.82 \mathrm{I}(2)$ & 4 & 1 & $-4.47 \mathrm{I}(1)$ & $\mathrm{I}(2)$ \\
\hline & Constant & 2 & 2 & $-10.01 \mathrm{I}(2)$ & 4 & 1 & $-4.93 \mathrm{I}(1)$ & $\mathrm{I}(2)$ \\
\hline & $\begin{array}{l}\text { Constant } \\
\text { and Trend }\end{array}$ & 2 & 1 & -10.20 & 3 & 1 & -5.71 & I (1) \\
\hline \multirow{3}{*}{ AGEXP } & None & 0 & 1 & -8.39 & 3 & 1 & -8.22 & I (1) \\
\hline & Constant & 0 & 1 & -8.70 & 3 & 1 & -8.49 & I (1) \\
\hline & $\begin{array}{l}\text { Constant } \\
\text { and Trend }\end{array}$ & 0 & 1 & -8.94 & 2 & 1 & -8.76 & I (1) \\
\hline
\end{tabular}

Table 6. Test Statistics and Choice Criteria for Selecting Order of the VAR Model

\begin{tabular}{|c|c|c|c|}
\hline Order & Log Likelihood & Akaike Information Criteria & Schwarz Criteria \\
\hline \multicolumn{5}{|c|}{ AGFDI, AGEXP } \\
\hline 0 & -1735.995 & 75.65194 & $78.81096^{* *}$ \\
\hline 1 & -1730.789 & $75.59993^{* *}$ & 75.91795 \\
\hline 2 & -1729.555 & 75.71977 & 76.19681 \\
\hline \multicolumn{5}{|c|}{ AGFDI, AGIMP } \\
\hline 0 & -170.367 & 74.53772 & 74.69673 \\
\hline 1 & -1697.280 & 74.14262 & $74.46064^{* *}$ \\
\hline 2 & -1691.167 & $74.05075^{* *}$ & 74.52778 \\
\hline
\end{tabular}

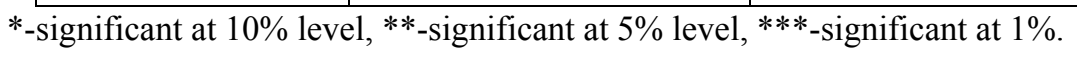


Table 7. Results of Granger-Causality Test

\begin{tabular}{|c|c|c|c|}
\hline & Equation & F-Value & p-value \\
\hline $\mathrm{H}_{\mathrm{o}}$ : AGIMP does not Granger Cause AGFDI & 9 & 4.10696 & $0.00^{* * *}$ \\
\hline $\mathrm{H}_{\mathrm{o}}$ : AGEXP does not Granger Cause AGFDI & 10 & 7.01058 & $0.00 * * *$ \\
\hline $\mathrm{H}_{\mathrm{o}}$ : AGFDI does not Granger Cause AGEXP & 11 & 0.03145 & 0.97 \\
\hline $\mathrm{H}_{\mathrm{o}}$ : AGFDI does not Granger Cause AGIMP & 12 & 6.10850 & $0.00 * * *$ \\
\hline
\end{tabular}

*-significant at $10 \%$ level, ${ }^{* *}$-significant at $5 \%$ level, ${ }^{* * *}$-significant at $1 \%$

Table 8. Results of Granger's Instantaneous Causality

\begin{tabular}{|c|c|c|c|c|}
\hline & \multicolumn{4}{|c|}{ Equations } \\
\hline & AGFDI (14) & AGFDI (15) & AGIMP (16) & AGEXP (17) \\
\hline Constant & -3301708 & -2557809 & $-36241224 * * *$ & 2845349 \\
\hline AGIMP & $-0.067224 *$ & - & - & - \\
\hline $\operatorname{AGIMP}(-1)$ & 0.007535 & - & $0.733378 * * *$ & - \\
\hline $\operatorname{AGIMP}(-2)$ & -0.004933 & - & $-0.342416^{* *}$ & - \\
\hline $\operatorname{AGIMP}(-3)$ & $0.098854 * *$ & - & $0.795545^{* * *}$ & - \\
\hline $\operatorname{AGIMP}(-4)$ & 0.042371 & - & 0.334028 & - \\
\hline AGEXP & - & -0.015794 & - & - \\
\hline $\operatorname{AGEXP}(-1)$ & - & $0.040490 * * *$ & - & $0.853699 * * *$ \\
\hline $\operatorname{AGEXP}(-2)$ & - & -0.011470 & - & 0.230704 \\
\hline AGFDI & - & - & $-1.430998 * *$ & -3.846406 \\
\hline AGFDI(-1) & $0.322392 *$ & $0.766601 * * *$ & $-1.753472 * *$ & 3.336898 \\
\hline AGFDI(-2) & 0.177436 & -0.166151 & $3.082206^{* * *}$ & -0.469311 \\
\hline F Value & $7.995319 * * *$ & $10.01338 * * *$ & $299.9938 * * *$ & $41.60570 * * *$ \\
\hline Adjusted R $^{2}$ & $53.24 \%$ & $50.01 \%$ & $97.98 \%$ & $81.85 \%$ \\
\hline D.W & $2.030098+$ & $1.877931+$ & $1.791553+$ & $1.936504+$ \\
\hline $\begin{array}{l}\text { Adjusted } \\
\text { Observations }\end{array}$ & 44 & 45 & 44 & 45 \\
\hline
\end{tabular}

*-significant at $10 \%$ level, ${ }^{* *}$-significant at $5 \%$ level, ${ }^{* * *}$-significant at $1 \%$. + -non-autocorrelated error terms 